\title{
The Physics of Ductile-brittle Machining Transitions: Single-point Theory and Experiment ${ }^{*}$
}

\author{
K. E. PUTTICK ${ }^{* *}$ and A. FRANKS ${ }^{* * *}$
}

Key words : single-point ductile machining, fracture transitions, theory and experiment

\section{Introduction}

One form of ductile machining of brittle materials that has been practised for many centuries and with great success is polishing and lapping: the gentle working conditions satisfy the criteria for ductile and damage-free machining. However, lapping and polishing do not accord with the requirements of present-day high technology which demands both rapid working and the machining of surfaces of complex shape.

Ductile grinding has the potential of overcoming the limitations of lapping technology. The machine tool requirement of a very precisely controlled cut is more easily realised for removal of thin plane layers of material but becomes progressively more difficult for thicker layers and surfaces of more complex shape. The generation of complex shapes generally requires the introduction of further interfaces in the tool control mechanism which may reduce the overall stiffness of the machine tool and thus reduce the control which can be exerted over the cutting process. Ductile grinding of thin plane layers is currently achievable and there appears to be no fundamental reason why the necessary machine tool technology could not be developed to cater for the ductile machining of complex forms. Many of the more

* 原稿受付 平成 2 年 2 月 8 日

** Department of Physics, University of Surrey (Guild. ford, Surrey GU2 5XH, UK)

*** National Physical Laboratory (Teddington, Middlesex, TW11 OLW) interesting potential applications of ductile grinding must therefore await further developments in machine tool technology.

Economic considerations provide a major stimulus for pursuing the development of ductile grinding technology : the objective is to eliminate entirely or very much reduce the costly and often labourintensive effort which is necessary at present to undertake either finishing to the requisite smoothness or the elimination of sub-surface damage. The applications are widespread and may be found in optics, electronics and mechanical engineering.

Diamond-turning is now commonly employed to manufacture optics with adequate surface finish for use in the infra-red. For shorter wavelengths, more stringent surface finish tolerances are required that could be met by ductile grinding. Ductile grinding differs from some other rapid finishing techniques where a glazed or "smeared-over" superficial high finish can be obtained, but which may yield an unstable substrate because of the sub-surface damage which was either generated or not eliminated by these finishing processes.

In visible optics, ductile grinding could become cost-effective in the manufacture of plane optical surfaces of the highest quality, such as those used in laser gyroscopes where surface finishes in the 0.2 $\mathrm{nm}$ region are required. Because of the difficulties encountered in the conventional manufacture of glass aspheric optics, cost-effectiveness would be also be achieved at poorer surface figure tolerance 
levels. The elimination of sub-surface damage is important in a wide variety of applications because it is responsible for light scatter and absorption leading, for example, to damage in high power laser systems and the impairment of resolution in astronomical optics.

Many X-ray optical components, both plane and curved, are candidates for finishing by ductile grinding. The larger synchrotron and astronomical X-ray components have a linear dimension in the region of $1 \mathrm{~m}$ and will present a considerable challenge to the machine tool manufacturer. However, some of the surface finish requirements for X-ray optics are so stringent that one would anticipate that ductile grinding with current or near-future technology would still have to be accompanied by at least a minimum of conventional lapping or polishing.

The applications in electronics differ from those in optics in that in the machining of semiconductors, extreme accuracy of surface figure over large areas is not generally as important as in optics, although increasing attention is now being paid to the standard of overall flatness of large silicon discs. Electronic properties are dependent on crystal lattice perfection and the demand is for zero subsurface damage. Important examples of materials where additional effort has to be employed (usually by chemical means and at the expense of surface figure) in eliminating sub-surface damage are silicon, gallium arsenide and indium phosphide. Surface perfection is important in multilayer electronic devices such as quantum wells where the layers may have thicknesses from less than $20 \mathrm{~nm}$ down to near atomic dimension.

Although the increasingly wide use of precision machine tools in the manufacture of optical components is narrowing the gap between mechanical engineering and optics manufacture, there are also a number of conventional engineering applications where the avoidance of sub-surface damage by ductile grinding will make a significant impact. The benefits of employing ceramic materials as engineering components are well-known, for example, as bearings and in high temperature applications in internal combustion engines. A drawback to their use is the machining cost, particularly the elimina- tion of the structure-weakening cracks produced by the conventional grinding process. It would be of substantial commercial importance if machines could be devised to grind ceramic turbine blades in a damage-free mode, because at present their complex shape requires them to be subjected to a tedious surface finishing procedure in order to remove the sub-surface cracks.

The process of grinding by abrasive tools can be understood only in terms of the contact mechanics of individual abrasive particles. We think it is important at this stage of knowledge, therefore, to review the scaling theory of fracture which underlies the brittle-ductile transition in machining, and its verification by recent experimental work. We emphasize first, the physical principle of energy scaling which is responsible for fracture transitions of all kinds, and second, the still imperfect state of understanding of the stress and strain fields generated by a sliding indenter.

\section{Theory of fracture transitions}

We are concerned here with fracture initiation transitions, i. e. with the borderline between cracking and no cracking. As always in brittle fracture, our primary understanding must be based on an analysis of the flow of energy which determines the propagation of a crack from a pre-existing flaw (which may be introduced by plastic deformation). This energy flows from an elastically strained volume to a crack surface, so that the energy supply scales at a different rate from energy demand as the size of a given operation changes: it is this nongeometrical "energy scaling" which is responsible both for the size effects observed in brittle fracture (Roesler 1956) and for fracture transitions of all kinds (Puttick 1980, Atkins and Mai 1985). The critical condition for brittle cracking is that the elastic tensile strain energy $U$ stored in a stressed volume shall be sufficient to supply the surface work $S$ required by the area $A$ of a growing crack (Griffith 1921)

$$
\frac{\mathrm{d} U}{\mathrm{~d} A} \geqq \frac{\mathrm{d} S}{\mathrm{~d} A}
$$

The right hand side of this expression is usually taken to be a constant $R$, a surface energy density. 
The left hand side scales linearly with the linear dimension $l$ of the stressed volume, and may be written as proportional to $l$ times a volume strain energy density $\sigma^{2} / E$, where $\sigma$ is a measure of the tensile stress and $E$ is Young's modulus. In plasticelastic problems the magnitude of $\sigma$ is determined by the uniaxial yield stress $\sigma_{y}$, so that finally we may express (1) in the form of a critical length $l_{c}$ below which cracks will not form:

$$
l_{\mathrm{c}}=\frac{\alpha E R}{\sigma_{\mathrm{y}}{ }^{2}}
$$

(Gurney and Hunt 1967, Puttick 1980).

$\alpha$ is a numerical constant characteristic of the test, being a measure of the size of strain field required to contain the necessary tensile strain energy. For fracture by plastic-elastic indentation, machining and similar processes it was estimated by Puttick et al. (1979) that $\alpha \sim 6.25$. Thus for glasses, where $E \sim 7 \times 10^{10} \mathrm{Nm}^{-2}, \quad \sigma_{\mathrm{y}} \sim 2 \times 10^{9} \mathrm{Nm}^{-2}, \quad R \sim 10$ $\mathrm{Jm}^{-2}$, a typical critical dimension below which brittle fracture should not occur is according to (2), $l_{c} \sim 1 \mu \mathrm{m}$. In single point machining, therefore, the depth of cut (which determines the range of tensile stress in machining) should be kept well below this figure.

\section{Experiments in Single-point Machining of \\ Glasses}

The prediction of a brittle-ductile machining transition based on energy scaling theory has been experimentally verified for single-point turning of a highly brittle glassy ceramic, fused quartz ("Spectrosil"), by Puttick et al. (1989). For this purpose they constructed a dedicated machine tool of very high stiffness. This consisted of a vertically mounted air bearing supported by a cast iron box carried by a massive metal frame suspended from an outer frame standing on four rubber load bearing joints. The cast iron box carried the tool arm in the form of a vertical tapered leaf spring on which was mounted a piezoelectric tool in-feed, the tool itself being a Vickers pyramid diamond indenter with a maximum apical angle of $136^{\circ}$. The DC motor drives of the tool arm and air bearing were completely separate, the tool drive providing a range of horizontal speeds from 0.09 to $21 \mathrm{~mm} \cdot \mathrm{min}^{-1}$.

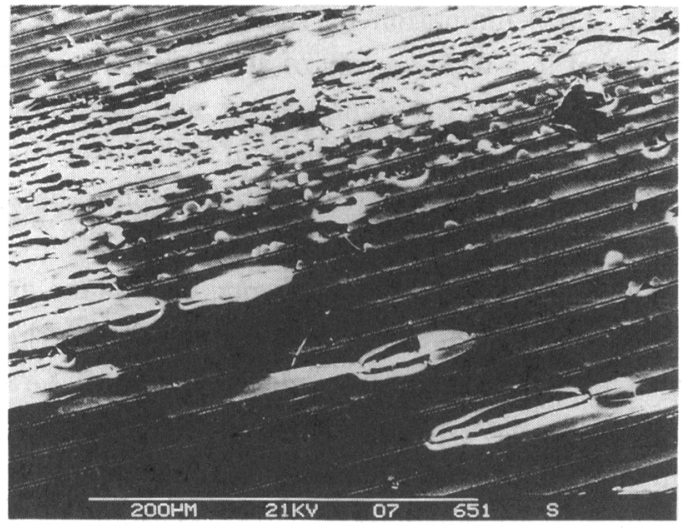

Fig. 1 Brittle chipping at grooves machined to a depth exceeding the critical value in Spectrosil. Speed $100 \mathrm{rev} \mathrm{min}^{-1}$

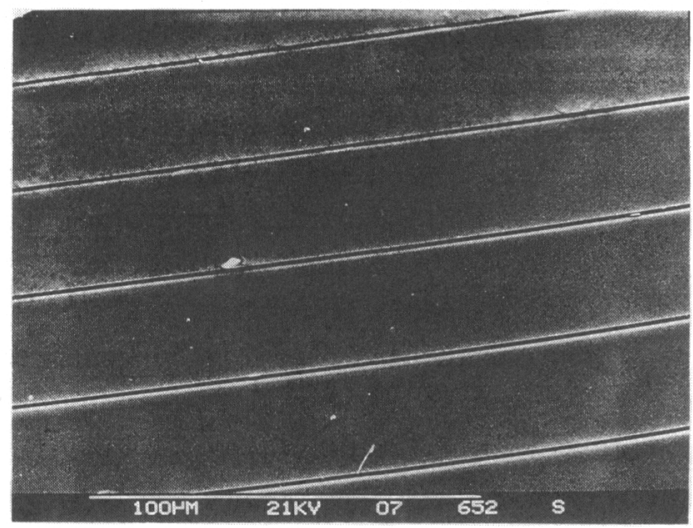

Fig. 2 Spiral groove machined in Spectrosil at a depth of about $0.25 \mu \mathrm{m}$. Speed $6 \mathrm{rev} \mathrm{min}^{-1}$

\section{Results}

Preliminary experiments on soda-lime glass blanks confirmed that the turning machine was performing to specification, with complete freedom from ground-borne vibration and high quality of cut. Spiral grooves were then made in plates of Spectrosil silica glass. Where the depth of cut exceeded a critical value of about $0.25 \mu \mathrm{m}$, brittle fracture occurred in the form of elongated chips (Fig. 1). Below this depth, crack-free machining was achieved, as shown in Fig. 2.

Certain regions of the spiral, however, revealed removal of material by a somewhat unexpected mechanism, illustrated by Figs. $3-5$. Fig. 3 is a general view of such a region, showing ribbons of 
swarf adhering to the cut in the form of tightly wound spirals. Closer examination, as in Fig. 4, shows a second feature of diagnostic interest: a series of arches of glass ribbon attached to the groove at both ends. Finally, Fig. 5 emphasizes that ribbons peeled off from the grooves are not necessarily confined to the width of the cut : a ribbon with a rather ragged edge is seen to be detaching itself from the side of the right-hand segment of groove.

\section{Discussion}

We believe that these experiments demonstrate the validity of our fundamental argument, that a brittle-ductile energy scaling transition exists and makes possible the machining of glass both by turning and grinding. We believe also that it has been shown that with a machine sufficiently free of vibration and of adequate loop stiffness any desired quality of surface is attainable. However, it is evident that even in the ductile regime the effect of residual stress must be taken into account.

It is obvious from close inspection of scanning electron micrographs of the machined grooves in Spectrosil that the ribbons of glass have been detached following the passage of the tool, and that this must be the consequence of residual stresses induced by plastic flow. No other explanation is possible, for example, for the formation of arches of swarf attached to the groove at both ends. It is evident, moreover, that the major principal residual stress must be compressive and directed along the groove: this would account both for the formation of arches and the curling up of the longer detached segments.

We propose that this removal of material occurs in two stages. We assume that the initial formation of the groove is a plastic-elastic process which results in a surface layer beneath it in a state of residual compression with a value $\sim \sigma_{y}$ (Puttick et al. 1989). Along the plastic-elastic boundary local delamination occurs to relieve elastic shear stresses, a process which may be regarded as a type of fracture subject to a strain energy criterion and thus associated with a critical depth of plastic zone. This delaminated segment may now buckle under the compressive stress acting at either end, so forming

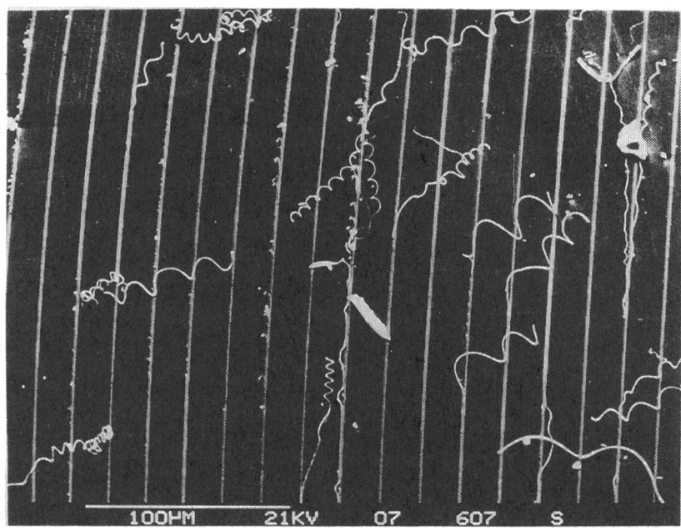

Fig. 3 General view of spiral swarf adhering to machined grooves in Spectrosil

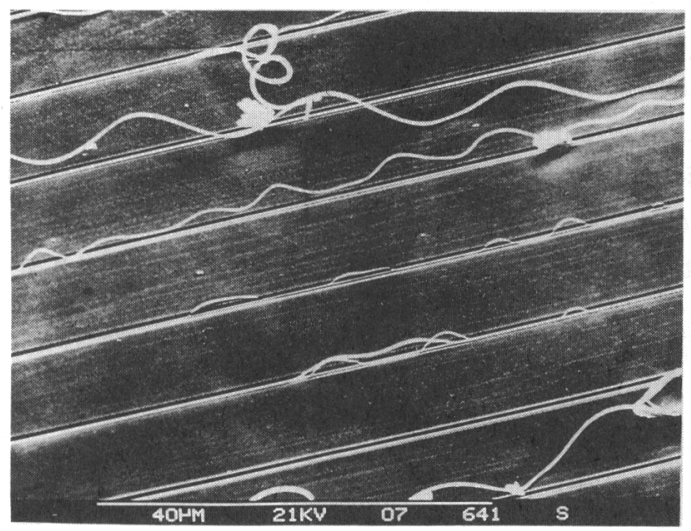

Fig. 4 Incipient detachment of swarf ribbons from machined grooves by arch formation

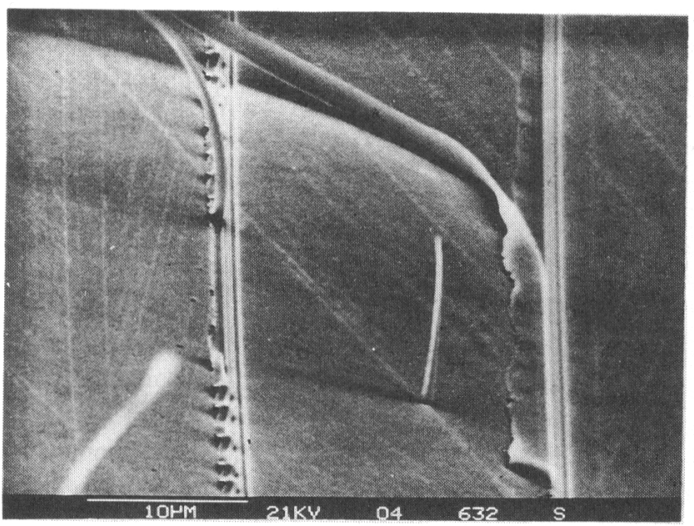

Fig. 5 Machined grooves in Spectrosil, showing (i) (right-hand segment) detachment of ribbon outside original groove, (ii) periodic rucking of groove material 
an arch of glass ribbon. This in turn results in bending moments with associated stored elastic energy tending to propagate a crack along the interface by plane strain (mode I) opening. In this way the buckle may enlarge in a self-similar way : alternatively the tensile stress at the top of the buckle may fracture the ribbon leaving two ends which may peel off separately under the action of the stored elastic energy. The latter mechanism we take to be that responsible for the growth of long spirals of swarf from the grooves. During this propagation of a stable crack along the plastic-elastic interface an important part is played by the compressive stress along the groove, which prevents premature breaking of the peeling segment.

Our experiments indicate, therefore, that there is indeed a critical depth in single point machining of amorphous silica within which uncontrolled fracture by chipping is inhibited by energy scaling considerations. There is nevertheless a second critical depth associated with the removal of material by stable peeling under residual stress : whether it will be necessary to keep the depth of cut below this to achieve the finest quality of surface, and whether the mechanisms of delamination, buckling and curlup are general (at least in homogeneous materials) are questions which remain to be determined. If so, they will certainly have repercussions in multipoint grinding as well as in single point techniques.

\section{References}

1) A. G. Atkins and Y. W. Mai: Elastic and Plastic Fracture, Ellis Horwood, Chichester, (1985).

2) A. A. Griffith: The Phenomena of Rupture and Flow in Solids, Phil. Trans. Roy. Soc., A 221, (1921) 163.

3) C. Gurney and J. Hunt: Quasi-static Crack Propagation, Proc. Roy. Soc., A 299, (1967) 508.

4) K. E. Puttick: The Correlation of Fracture Transitions, J. Phys. D : Appl. Phys., 13, (1980) 2249.

5) K. E. Puttick, M. A. Shahid and M. M. Hosseini : Size Effects in Abrasion of Brittle Materials, J. Phys. D., 12, (1979) 195.

6) K. E. Puttick, M. R. Rudman, K. J. Smith, A. Franks and K. Lindsey: Single Point Diamond Machining of Glasses, Proc. Roy. Soc., A 426, (1989) 19.

7) F. Roesler: Brittle Fractures near Equilibrium, Proc. Phys. Soc., B 69, (1956) 981. 


\section{加工における延性一ぜい性遷 移のカ学：シングルポイント 工具による実験と理論}

ラッピングとポリシングはぜい性材料を延性破壊 モードで加工面に損傷を与えずに加工する方法として 活用されてきたが，複雑な曲面を能率良く加工したい とい5今日の高度技術のニーズに対応でさない，延性 モード研削はこのラッピング技術の限界を克服できる 可能性をもっている. ぜい性材料の曲面の延性モード 研削が可能な研削盤の開発は, 運動精度や剛性の点で 敩しい性能を要求されるが, 基本的には不可能な理由 は無いと考えられる.

延性モード研削技術の開発の大きな理由の一つに経 斎的要因がある. 平滑面の加工や加工面の損傷を除去 するための加工に要するコストの低減である.

延性モード研削の適用分野は光学, エレクトロニク ス，機峨技術に及ぶであろう．光学分野ではダイヤモ ンド切削の適用分野である赤外線分野を除さ，これよ り短波長の可視光から X 線領域の平面および曲面の 高い形状精度と無損傷の加工を必要とする分野が対象 となる. 半導体分野では一般に光学分野ほど広い面積 にわたる高い精度を要求されないが, 大口径のシリコ ンウエハの平坦度が問題となっている. 機械技術分野 では微小クラックの存在が強度の低下をもたらすセラ ミックスの加工などが対象となる.

加工に拈ける破壊発生の遷移の問題は, 材料内部の エネルギーの流れに着目した破壊理論に基礎をおかな ければならない，ぜい性破壊の場合，この流れは弾性 ひずみをもつ媒質からき裂面への流れである.グリ フィスによればぜい性破壊が起こる臨界条件は次式で 示される. ここで $U$ は媒質の弾性ひずみエネルギー, $S$ はき裂面の表面エネルギー，A $A$ 進展き裂面の面 樍である.

$$
\frac{\mathrm{d} U}{\mathrm{~d} A} \geqq \frac{\mathrm{d} S}{\mathrm{~d} A}
$$

右㲽は定数で材料の表面エネルギー密度, 左辺は応力 を受ける媒質の寸法 $l$ とひずみェネルギー密度 $\sigma^{2} / E$ の積に比例する． $\sigma$ は引張応力を表し， $E$ はヤング率
である. 弾塑性問題では $\sigma$ は単軸降伏応力 $\sigma_{\mathrm{y}}$ で決定 されるから, き裂生成の臨界値 $l_{\mathrm{c}}$ は次式で表せる.

$$
l_{\mathrm{c}}=\frac{\alpha E R}{\sigma_{\mathrm{y}}{ }^{2}}
$$

定数 $\alpha$ は所要の引張りひずみエネルギーを含むのに 必要なひずみ場の大きさを表し, 弾塑性的押込みテス トや加工による破壊の場合 $\alpha=6.25$ である. ガラス の場合, ぜい性破壊が起こらない臨界值 $l_{\mathrm{c}}$ は式 (2) から約 $1 \mu \mathrm{m}$ となる. シングルポイント工具による加 工の場合, 引張応力の範用を決める切込み深さをこの 值以下に保つ必要がある.

理論を検証するために, 振動の絶縁と剛性に留意し た加工機を試作して，ェアスピンドルの端面に取り付 けた溶融水晶に頂角 $136^{\circ}$ のダイヤモンド圧子でスパ イラル状の溝を加工する実験を行い, ぜい性破壊が起 こる臨界切込み深さが $0.25 \mu \mathrm{m}$ であることを確認し た.さらに，電子顕微鏡による切りくずの観察の結 果, 切りくずが工具の通過した後で切削溝から分離す ること, これが塑性流動によって生じた残留応力の作 用によること，この残留応力の主成分が溝方向の圧縮 応力であることがわかった。

以上の結果から材料除去は 2 段階で起こると考えら れる. 溝が形成される最初の段階は弾塑性プロセス で, 溝の表層に大きさ $\sigma_{\mathrm{y}}$ の圧縮応力が残留する。こ の弾塑性境界に沿って弾性ひずみエネルギーを解放す るための局部的な葉裂が生じ，この葉裂部分を起点と して安定なき裂の伝播が起こって切りくずが生成され る.この一連のプロセスでは残留厈縮応力が重要な働 きをする.

溶融水晶の切削の場合, エネルギー則に基づくチッ ピングによる制御不能の破壊発生を支配する臨界深さ が存在し,さらに残留応力の下で安定な切りくず生成 が行われる第二の臨界深さがあることがわかった. 高 品位の仕上面を得るために切込又を第二の臨界値以下 に保つ必要があるのか, この切りくず生成機構が一般 性をもつのかは残された課題である.もしこれが正し ければ，シングルポイント工具の場合と同様に，研削 に怙いても重要な意味をもつことになろう.

\section{著者紹介}

National Physical Laboratory (NPL) は英国国立の研究 機関. Dr. FranksはNPL の Mechanical and Optical Measurement 部門に所属し，英国に括ける精密測定分野 のリーダ. 英国のナノテクノロジープロジェクトの推進者 でもある. Warwick 大学の客員教授も務める.X線工学 の研究者としても著名. Prof. Puttick は Surrey 大学物理 学科教授. 1980 年初頭から加工に拁ける破壊現象につい ての研究報告を行っている. 